\title{
INTERNATIONALISING CONDUCTIVE EDUCATION REPORTS FROM RECENT ADVANCES IN CONDUCTIVE EDUCATION ${ }^{10}$
}

\author{
Authors: \\ Adrienn Oravecz \\ Eszterházy Károly University
}

E-mail address of the first author:

ora_adri@msn.com

\author{
Lectors:
}

\author{
Tünde Rózsahegyi \\ University of Wolverhampton \\ Magdolna Estefánné Varga \\ Eszterházy Károly University \\ Veronika Schéder \\ University of Debrecen \\ Katalin Mező \\ University of Debrecen
}

Oravecz, Adrienn (2017): Internationalising conductive education: reports from recent advances in conductive education. Különleges Bánásmód, III. évf. 2017/1. szám, 101-103. DOI 10.18458/KB.2017.1.101

Bibliography of the subject of this recension:

Sutton, Andrew and Maguire, Gillian (2010): Internationalising conductive education. Birmingham (England): Conductive Education Press. ISBN 978-0-9569948-1-3

Keywords: Conductive Education, Different Social Context, Therapies for cerebral palsy

Disciplines: Special Education, Conductive Education

The editors of the book are Andrew Sutton and Gillian Maguire. Andrew Sutton has been involved with Conductive Education since 1979. He contributed to the political movement to introduce Conductive Education into the UK. Then in 1986, helped to found Foundation for Conductive Education, directing it till he retired in 2004. Before that his personal collection of written materials about Conductive Education formed the basis of the National Library of Conductive Education in Birmingham, England, and he created the journal Recent Advances in Conductive Education. Since retirement he also helped to create Conductive Education Press, and blogs at www.conductive.world.info.which collects up to date information about Conductive Education worldwide.

Gillian Maguire is The Librarian of the National Library of Conductive Education from 1991. The basis of the library was Andrew Sutton's personal collection but over the years it has grown over 6000 items. The library tries to reflect on the spread and development of

\footnotetext{
${ }^{10}$ The editorial board does not take any responsibilty for the English of the papers. Indeed, we made some slight changes but wanted to keep the style of the authors.
} 
Conductive Education. The goal of the Conductive Education Press is to stimulate new publications in the field of Conductive Education where Gillian works as the co-editor. In 2008 she started a blog Conductive Education Information to inform those interested in CE about new publications, articles internet sites, new centres etc. and offering an enquiry service. In 2010 she established the Virtual Catalogue of CE materials which is available on http://www.e-conduction.org/virtual-library-catalogue/. In 2011 she created and still maintain the World Map of Where Conductors Work available on http://www.e-conduction.org/whereconductors-work/. Both of them received the Honorary Conductor Award, Andrew Sutton in 1990 and Gillian Maguire in 2010.

In introductory part written by the editors the reader was informed about a journal Recent Advances in Conductive Education which appeared twice a year from 2001 to 2009. It was not a proper journal in the sense of collecting pre-reviewed articles written and accepted by an academic comitee. The journal was ended because those who were involved in Conductive Education they had no capacity to do this further while they had to solve more pressing things in their daily work. The other reason was there was no and still has not got a coherent academic wing in this field. It is a sorrowful event that since the death of Mária Hári has no academic journal of the Petö Institute. There was the Conductive Education Papers in which the staff of the institute published in a foreign language. Now they have an online journal but not a pre-reviewed one and the articles written exclusively in Hungarian called Science and Profession. In my opinion this good but if they want a spirited conversation and stronger cooperation with foreign Conductive Education Centres in the near future they really should issue materials in English as well which is appropriate to the academic publishing standards. What makes this book unique it gives a written record of the internationalising process of Conductive Education, there is no other accessible documentation about how did it happened outside Hungary. Fourteen articles were selected into the book. Authors were asked to give a brief update of where things stand in 2010. I would be very curious about what has happened since 2010 up to the present day.

The first article described how Conductive Education was brought to Sheffield. In 2010 the Places School has a greater financial viability a step nearer the mainstream of conductive education and a small measured of increased choice for parents. The project could not accomplish the transition to create an alternative for young adults. This is one of the recurrent topics of Conductive Education. I said it previously that it would be very urgent to support young adults because with ageing their condition decreasing day by day. If they are not healthy enough they will not be able to work and earn money to finance their own cost of living. This is a vicious circle and constant dependence from society and family is very frustrating.

The second article had not got a happy ending because it depicted a long process how Conductive Education was introduced in California but the service was finished in November of 2008.

The third article informed the reader about a successful adaptation of Conductive Education in Israel. In 2010 Andrew Sutton wrote the following: "The base establishment by Tsad Kadima's pioneers had provided firm footing for extensive subsequent development" (Sutton and Maguire p.49 )The process of development was collected into a book which was introduced at $9^{\text {th }}$ World Congress on Conductive Education in December of 2016.

The forth article presents the situation in Norway. Norsk Forum for Konduktiv Pedagogik is a parent-owned and parent-run organisation in Hamar. In October 2004 another was opened offering services for adults in the town Stavanger. The centre provides short-term courses and weekly sessions for Prkinson's disease, young adults with cerebral palsy and children with dyspraxia. The writer of the articles listed the challenges she had to face with as a conductor. First, little or nothing was known in relation to her work with adults. Second, explanation of 
her profession was problematic too so finally she came up with the idea she is a special pedagogue in the field of motor disorders. In 2010 Keri Hapnes the author concluded the process in the following way: The job of the conductor had become more recognised and more respected although the change of the professional title was necessary using the term rehabilitation pedagogue instead.

The last article I would like to mention is the Mexican model. What I really liked that they used art to advertise Conductive Education. A talented boy called Ekiwah Adler was mentioned who wrote poetry and plays which were presented in workshops. Other children were gifted in painting so they organised exhibitions for them. The experience of these children were filmed in 2003. The film got the Ariel prize a national prize for the best documentary of the year. From 2008 to 2010 they had enough resource to hire some experienced conductor from the Pető Institute. As a next step they would like to provide formal training and constitute a training centre for those who would like to be a conductor. Discussions started with the Pető András College.

This book is recommended who would like to know more about Conductive Education. I wish you pleasant reading! 